DOI: $10.15193 /$ zntj/2019/121/316

\author{
ANNA WIRKIJOWSKA, PIOTR ZARZYCKI, KAZIMIERZ NOWOROLNIK, \\ DANUTA LESZCZYŃSKA

\section{EFFECT OF NITROGEN FERTILISATION ON TECHNOLOGICAL VALUE OF SPRING BARLEY GRAIN}

\begin{abstract}
S u m m a r y
The objective of the research study was to determine the effect of nitrogen fertilisation level on changes in the technological value of five spring barley cultivars intended for food production. A pot experiment with spring barley was performed in the greenhouse run by the Institute of Soil Science and Plant Cultivation. The barley cultivars studied were compared for the quantity and quality of grain yield including their response to three levels of nitrogen fertilisation $\left(\mathrm{NH}_{4} \mathrm{NO}_{3}\right): 1,2$ and $3 \mathrm{~g} \mathrm{~N} /$ pot. The nitrogen fertilisation level proved to have a significant effect on the yield and quality of grains of the barley cultivars examined. With the increase in the nitrogen dose levels to $3 \mathrm{~g} / \mathrm{pot}$, a significant increase was reported in the grain yield and number of spikes per pot in all the spring barley cultivars, however there was a decrease in the weight of 1000 kernels. The levels of nitrogen fertilisation and the barley cultivars proved to have a significant impact on the contents of total dietary fibre (TDF) and $(1,3)(1,4)-\beta$-D-glucans but no interaction was found between the level of fertilisation and the cultivar. Significantly higher contents of TDF and $(1,3)(1,4)-\beta$-D-glucans were reported in the examined spring barley cultivars at a dose of 2 and $3 \mathrm{~g} \mathrm{~N} / \mathrm{pot}$ compared to $1 \mathrm{~g} \mathrm{~N} /$ pot. With the increase in the nitrogen dose to $3 \mathrm{~g} \mathrm{~N} /$ pot, a significant increase was reported in the protein content in all the cultivars. Owing to the highest contents of dietary fibre and $(1,3)(1,4)-\beta$-D-glucans, and to a high protein content, the 'Bordo' and 'Tocada' varieties can be recommended as the best varieties to produce food.
\end{abstract}

Key words: barley, fertilisation, quality, dietary fibre, Mitscherlich pot

\title{
Introduction
}

Barley is one of the most important cereal crops in Europe and world-wide. It ranks fourth in the world cereal production (147 Mt per year is the average over the

Dr inż. A. Wirkijowska, dr inż. P. Zarzycki, Zakład Inżynierii i Technologii Zbóż, Katedra Technologii Surowców Pochodzenia Roślinnego i Gastronomii, Wydz. Nauk o Żywności i Biotechnologii, Uniwersytet Przyrodniczy w Lublinie, ul. Skromna 8, 20-704 Lublin, prof. dr hab. K. Noworolnik, dr hab. D. Leszczyńska, Zakład Uprawy Roślin Zbożowych, Instytut Uprawy Nawożenia i Gleboznawstwa Państwowy Instytut Badawczy, ul. Czartoryskich 8, 24-100 Puławy.

Kontakt:piotr.zarzycki@up.lublin.pl 
period from 2015 to 2017) after maize, wheat and rice [7]. Therefore it is important to know the effects of both the agronomic factors and the properties of barley cultivars on the quantity and quality of grain yield in view of using barley cultivars in food production. For example, the level of nitrogen fertilisation proves to have a high effect on both the yield and quality of barley. The nitrogen fertilisation helps increase the size and structure of grains, whereas its chemical composition depends on the environmental conditions and characteristics of the cultivar [17, 18, 21]. An increase in nitrogen fertilisation positively affects the yield of barley grain to a certain limit of $\mathrm{N}$ dose, which depends on the nitrogen abundance in the soil. A further increase in the concentration of nitrogen in soil causes the grain yield to stagnate and then to decrease owing to the increase in plants lodging; also it causes pest infestation and other diseases. The nitrogen fertilisation increases the tillering of plants. With an increasing dose of nitrogen the protein content in grain also increases (to varying degrees in different cultivars), even if the grain yield decreases. The effect of nitrogen fertilisation also depends on the characteristics of the cultivar [20]. Those differences result from morphological and physiological features of the cultivar (e.g. capacity of plant tillering, light requirements, efficiency of nitrogen utilization, rigidity and elasticity of blades).

In the reference literature, the effect is known of various agronomic factors and features of cultivars on the quality of barley grain used for brewing purposes, however there are no data regarding the effect of agronomic factors and features of cultivars on the quality of grain designed for use in food products (e.g. grits, flakes, bread). According to the WHO's [25] statistical data reports there is an increase in the incidence of diet-related lifestyle diseases in adults and children, which in turn indicates the need to change eating habits and to increase daily physical activity. The consumption of whole-grain and low-processed cereal products (grits, "hot meals" type flakes, wholegrain bread) is known to be one of the factors to cause overweight and obesity [4, 12, $13,22]$. Dietary fibre plays a crucial role in controlling obesity (at least $30 \%$ of dietary fibre should be represented by a soluble fraction) [9]. The human body requires 20 to $40 \mathrm{~g}$ of dietary fibre per day on average to function properly and to maintain life [11, 12]. The actual daily dietary fibre intake ranges from 13.5 to $26.3 \mathrm{~g} /$ day as for UK and Germany, respectively, and $20 \mathrm{~g}$ /day for the US residents [6, 8]. In the Global Burden of Disease study [10] exposure to a diet low in fibre is defined as an average daily consumption level of less than $23.5 \mathrm{~g}$ /day. Therefore high-fibre cereal products with a high content of soluble fraction including $(1,3)(1,4)-\beta$-D-glucans are highly recommended and they are considered a desirable food ingredient. Research has shown the beneficial effects of barley fibre and, in particular, of $(1,3)(1,4)-\beta$-D-glucans on human health $[2$, $16]$.

A proper ratio of insoluble and soluble dietary fibre (IDF and SDF, respectively) in the diet provides comprehensive, preventive and health-promoting effects. IDF pro- 
tects human body primarily against gastric disorders. IDF retains its structure in the colon, thereby supporting the process of intestinal peristalsis and preventing constipation. In turn, in the colon SDF is subjected to fermentation processes resulting in the formation of $\mathrm{CO}_{2}$, methane and short-chain fatty acids, such as butyric acid; this causes the $\mathrm{pH}$ value of the intestinal content to decrease and for that reason the development of lactobacilli and streptococci is stimulated. This inhibits the growth of spoilage bacteria. The interaction between IDF and SDF provides an anticarcinogenic effect in the treatment and prevention of colorectal cancer [19]. Moreover, IDF and SDF have proved to have a combined effect by decreasing hypercholesterolemia and hypoglycaemia, so they are also applied to treat and prevent overweight, obesity and cardiovascular diseases $[2,13,14,22,26]$.

Thus, further scientific research is needed on the quality of grain intended for food purposes and for the utilisation in the production of food with functional features. In particular those barley cultivars should be selected that have a fractional composition and contain protein, dietary fibre and $(1,3)(1,4)-\beta$-D-glucans. Also it is absolutely essential to determine the impact of genetic and agronomic factors on changes in the functional properties of barley grain.

The objective of the research study was to compare the response of novel cultivars of spring barley to the increasing of nitrogen fertilisation level in terms of grain yield and yield components and especially in terms of the content of protein and dietary fibre in the grain.

\section{Material and methods}

A pot experiment with spring barley was performed in the greenhouse run by the Institute of Soil Science and Plant Cultivation (IUNG - PIB) in Puławy. Mitscherlich pots were used to study the following barley cultivars: 'Afrodite', 'Bordo', 'Henrike', 'KWS Olof' and 'Tocada'. In particular there were analysed the responses of those barley cultivars to three different levels $(1,2$ and $3 \mathrm{~g} / \mathrm{pot})$ of nitrogen fertilisation $\left(\mathrm{NH}_{4} \mathrm{NO}_{3}\right)$. Nitrogen doses of 1 and $2 \mathrm{~g}$ /pot were divided into two parts: $60 \%$ before sowing $+40 \%$ at the end of tillering. The $3 \mathrm{~g} \mathrm{~N} /$ pot dose was divided into three parts: $60 \%$ before sowing $+25 \%$ at the end of tillering $+15 \%$ before the heading. The pots were fertilised with other mineral components; their doses were as follows: $0.8 \mathrm{~g}$ P; $1.7 \mathrm{~g} \mathrm{~K} ; 0.4 \mathrm{~g} \mathrm{Mg} ; 50 \mathrm{mg} \mathrm{Fe} ; 5 \mathrm{mg} \mathrm{B}$ and $3 \mathrm{mg} \mathrm{Cu}$ per pot. The seeds were sowed at the end of March. The plant density was stable; in every pot there were 10 plants left in two leaf phase stages (after thinning). The soil humidity was kept at $60 \%$ of the field water capacity. The experiment was set up with the use of a method of independent series in four replications.

After harvesting barley the grain yield and the characteristics of its structure were determined. In addition there were determined the chemical composition of the culti- 
vars examined, i.e. the content of crude protein (Method AACC 46-08), the total dietary fibre (TDF), IDF and SDF. The determination was performed using an enzymatic method (AOAC 991.43, AACC 32-07, AACC 32-21, AOAC 985.29, AACC 32-05). In addition the content of $(1,3)(1,4)-\beta$-D-glucans was analyzed (AACC 32-23, AOAC 995.16) $[1,3]$. For the purpose of this research a set of enzymes was utilised and analytical procedures from a Megazyme company (Bray, Ireland). The results obtained were statistically analysed using a two-way analysis of variance with replication (ANOVA, Statistica 13) and with two factors: levels of nitrogen fertilisation and barley cultivar. A Tukey's range test $(\mathrm{p} \leq 0.05)$ was applied to identify a statistical significance of differences between the mean values.

\section{Results and discussion}

Under the research study, the effect was determined of the nitrogen fertilisation level on the grain yield of spring barley, yield components and grain quality. The increasing of the nitrogen concentration rate to $3 \mathrm{~g} /$ pot had a positive effect on the grain yield and the number of spikes per pot (Tab. 1).

Table 1. Grain yield and yield components of spring barley depending on nitrogen dose (N dose) Tabela 1. Plon ziarna i składniki plonu jęczmienia jarego w zależności od dawki azotu (dawka N)

\begin{tabular}{||c|c|c|c|c||}
\hline $\begin{array}{c}\text { N dose [g/pot] } \\
\text { Dawka N } \\
\text { [g/wazon] }\end{array}$ & $\begin{array}{c}\text { Grain yield [g/pot] } \\
\text { Plon ziarna } \\
\text { [g/wazon] }\end{array}$ & $\begin{array}{c}\text { Number of spikes } \\
\text { per pot / Liczba } \\
\text { kłosów na wazon }\end{array}$ & $\begin{array}{c}\text { Number of grains } \\
\text { per spike / Liczba } \\
\text { ziaren w kłosie }\end{array}$ & $\begin{array}{c}\text { Weight of 1000 } \\
\text { grains / Masa } \\
1000 \text { ziaren [g] }\end{array}$ \\
\hline 1 & $50.9^{\mathrm{c}} \pm 3.3$ & $40.2^{\mathrm{c}} \pm 3.8$ & $24.7^{\mathrm{a}} \pm 2.1$ & $52.9^{\mathrm{a}} \pm 1.5$ \\
2 & $62.7^{\mathrm{b}} \pm 4.2$ & $67.4^{\mathrm{b}} \pm 3.5$ & $18.8^{\mathrm{b}} \pm 2.2$ & $51.7^{\mathrm{a}} \pm 0.9$ \\
3 & $68.0^{\mathrm{a}} \pm 5.3$ & $75.3^{\mathrm{a}} \pm 4.1$ & $18.7^{\mathrm{b}} \pm 1.8$ & $49.3^{\mathrm{b}} \pm 0.5$ \\
\hline
\end{tabular}

Explanatory notes / Objaśnienia:

Table shows mean values \pm standard deviations / W tabeli przedstawiono wartości średnie \pm odchylenia standardowe; $\mathrm{a}, \mathrm{b}, \mathrm{c}$ - mean values in columns and denoted by different letters differ statistically significantly $(\mathrm{p} \leq 0.05)$ / wartości średnie w kolumnach oznaczone różnymi literami różną się statystycznie istotnie $(\mathrm{p} \leq 0,05)$.

All the cultivars yielded significantly higher at a nitrogen dose of $2 \mathrm{~g}$ compared to $1 \mathrm{~g} \mathrm{~N} /$ pot. There was no interaction between the cultivar and the fertilisation (Fig. 1). An increase in grain yield was reported for all the cultivars studied; however, this increase was not statistically significant for all of them. Compared to a $1 \mathrm{~g} \mathrm{~N} /$ pot dose, at $2 \mathrm{~g} \mathrm{~N} /$ pot the grain yield increased; this increase was higher compared to the grain yield in the case of $3 \mathrm{~g} \mathrm{~N} /$ pot. The above research finding was in line with that as reported by Noworolnik et al. [19] for the 'Basza', 'Skarn' and 'Wanad' cultivars. The increasing of the concentration rate of nitrogen caused the grain yield to increase as 
a consequence of the stronger productive tillering of plants that generated an increase in the number of spikes per pot.

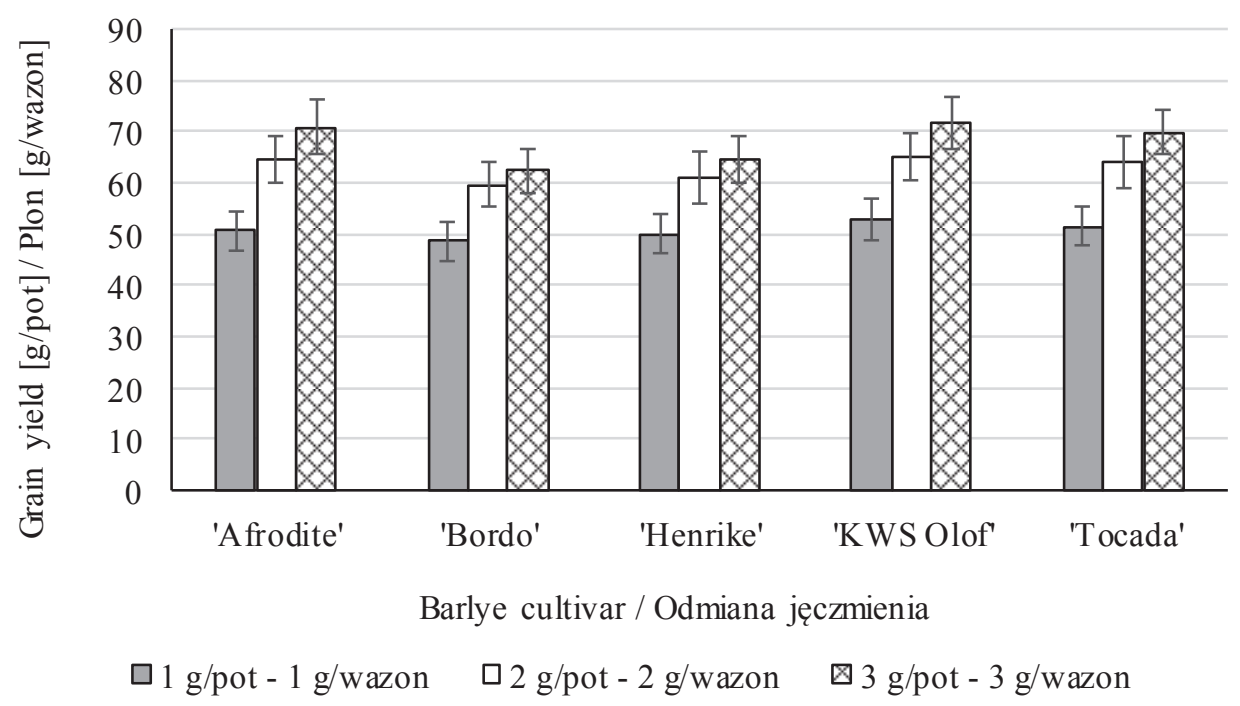

Fig. 1. Effect of barley cultivar and nitrogen dose [g/pot] on grain yield level [g/pot]

Rys. 1. Wpływ odmiany jęczmienia i dawki azotu [g/wazon] na wielkość plonu ziarna [g/wazon]

The characteristics of spring barley spike production were less differentiated under the impact of nitrogen than the number of spikes (Tab. 1). As for all the cultivars studied, a significantly higher number of grains per spike was found in the case of $1 \mathrm{~g}$ $\mathrm{N} /$ pot compared to higher concentration rates of nitrogen. The weight of 1000 grains was significantly reduced at higher concentration rates of nitrogen.

As yet there are no studies dealing with the response of novel spring barley cultivars (i.e. those examined under the present research) to the increasing of nitrogen fertilisation level in terms of the size and structure of grain. The response of older cultivars of spring barley to the nitrogen fertilisation level was compared in the previous pot experiments conducted by IUNG in Puławy $[17,19]$. Those cultivars differed in their response to $3 \mathrm{~g} \mathrm{~N} /$ pot as some of them showed an insignificant increase in the grain yield when compared to $2 \mathrm{~g} \mathrm{~N} /$ pot. Other cultivars yielded significantly higher. Therefore a conclusion is possible that the cultivars that are naturally characterized by lower tillering strongly increase the grain yield and the number of spikes in the pot owing to a greater concentration rate of nitrogen.

Between the examined cultivars of spring barley statistically significant differences were found in the size of grain, the weight of 1000 grains and the number of spikes and kernels in the spike (Tab. 2). The obtained results confirm the findings of Moreno et al. [15] and Wyszyński et al. [27]. The highest values of the examined fea- 
tures were confirmed for 'Afrodite', 'KWS Olof' and 'Tocada' cultivars. In the reference literature there is lack of information on the elements of grain structure of the examined cultivars.

Table 2. Grain yield components of spring barley cultivars (mean values for $\mathrm{N}$ dose)

Tabela 2. Składniki plonu ziarna odmian jęczmienia jarego (wartości średnie dla dawki N)

\begin{tabular}{||c|c|c|c|c||}
\hline \hline $\begin{array}{c}\text { Cultivar } \\
\text { Odmiana }\end{array}$ & $\begin{array}{c}\text { Grain yield [g/pot] } \\
\text { Plon ziarna } \\
\text { [g/wazon] }\end{array}$ & $\begin{array}{c}\text { Number of spikes } \\
\text { per pot / Liczba } \\
\text { kłosów na wazon }\end{array}$ & $\begin{array}{c}\text { Number of grains } \\
\text { per spike / Liczba } \\
\text { ziaren w kłosie }\end{array}$ & $\begin{array}{c}\text { Weight of 1000 } \\
\text { grains / Masa 1000 } \\
\text { ziaren [g] }\end{array}$ \\
\hline 'Afrodite' & $62.1^{\mathrm{a}} \pm 9.9$ & $64.3^{\mathrm{a}} \pm 2.2$ & $19.8^{\mathrm{b}} \pm 0.8$ & $49.2^{\mathrm{ab}} \pm 1.2$ \\
'Bordo' & $57.1^{\mathrm{b}} \pm 7.3$ & $58.0^{\mathrm{c}} \pm 1.8$ & $20.2^{\mathrm{ab}} \pm 1.6$ & $48.7^{\mathrm{b}} \pm 1.4$ \\
'Henrike' & $58.2^{\mathrm{b}} \pm 7.6$ & $58.7^{\mathrm{bc}} \pm 2.5$ & $19.6^{\mathrm{b}} \pm 0.9$ & $51.1^{\mathrm{a}} \pm 1.2$ \\
'KWS Olof' & $63.5^{\mathrm{a}} \pm 9.1$ & $61.1^{\mathrm{b}} \pm 1.7$ & $21.8^{\mathrm{a}} \pm 1.1$ & $47.6^{\mathrm{b}} \pm 1.6$ \\
'Tocada' & $61.8^{\mathrm{ab}} \pm 9.0$ & $61.3^{\mathrm{b}} \pm 2.1$ & $20.5^{\mathrm{ab}} \pm 1.5$ & $49.1^{\mathrm{ab}^{\mathrm{b}} \pm 1.3}$ \\
\hline
\end{tabular}

Explanatory notes as in Tab. 1. / Objaśnienia jak pod tab. 1.

Research has shown that the chemical composition of spring barley grain was dependent on the applied nitrogen dose (Tab. 3). The protein content in husked spring barley is in the range of $9.6 \div 14.4 \%$ d.m. $[14,17,19]$. The average protein content in the cultivars examined ranged from 9.8 to $13.2 \%$ d.m. at 1 and $3 \mathrm{~g} \mathrm{~N} /$ pot, respectively.

Table 3. Content of selected chemical components in grain of spring barley [\% d.m.] depending on nitrogen dose

Tabela 3. Zawartość wybranych składników chemicznych ziarna jęczmienia jarego [\% s.m.] w zależności od dawki azotu

\begin{tabular}{|c|c|c|c|c|c||}
\hline $\begin{array}{c}\text { N dose [g/pot] } \\
\text { Dawka N } \\
\text { [g/wazon] }\end{array}$ & TDF & SDF & IDF & $\begin{array}{c}(1,3)(1,4)-\beta \text {-D-glucans } \\
(1,3)(1,4)-\beta \text {-D-glukany }\end{array}$ & $\begin{array}{c}\text { Protein } \\
\text { Białko }\end{array}$ \\
\hline 1 & $21.2^{\mathrm{b}} \pm 1.7$ & $4.5^{\mathrm{b}} \pm 0.3$ & $16.7^{\mathrm{a}} \pm 0.6$ & $3.4^{\mathrm{b}} \pm 0.42$ & $9.8^{\mathrm{c}} \pm 0.8$ \\
2 & $22.1^{\mathrm{a}} \pm 1.7$ & $4.9^{\mathrm{a}} \pm 0.2$ & $17.2^{\mathrm{a}} \pm 0.8$ & $4.1^{\mathrm{a}} \pm 0.47$ & $11.7^{\mathrm{b}} \pm 0.9$ \\
3 & $22.5^{\mathrm{a}} \pm 1.8$ & $5.0^{\mathrm{a}} \pm 0.3$ & $17.5^{\mathrm{a}} \pm 0.6$ & $4.4^{\mathrm{a}} \pm 0.53$ & $13.2^{\mathrm{a}} \pm 1.1$ \\
\hline
\end{tabular}

Explanatory notes / Objaśnienia:

TDF - total dietary fibre / błonnik pokarmowy całkowity; SDF - soluble dietary fibre / błonnik pokarmowy rozpuszczalny; IDF - insoluble dietary fibre / błonnik pokarmowy nierozpuszczalny. Other explanatory notes as in Tab. 1. / Pozostałe objaśnienia jak pod tab. 1.

The increase in the nitrogen fertilisation level caused the total protein content to increase similarly as in the research studies by Noworolnik [17] and Noworolnik et al. [19]. In the authors' own study the cultivar proved to have a minor effect on the protein content. Compared to other cultivars, the highest amount of protein content was reported in the 'Henrike' cultivar $-12 \%$ d.m. Furthermore, significantly lower protein con- 
tent was found in the 'Afrodite' and 'KWS Olof' cultivars compared to other cultivars (Tab. 4).

Table 4. Content of selected chemical components in grain of spring barley cultivars (average of $\mathrm{N}$ dose) [\% d.m.]

Tabela 4. Zawartość wybranych składników chemicznych w ziarnie odmian jęczmienia jarego (średnia z dawki N) [\% s.m.]

\begin{tabular}{||c|c|c|c|c|c||}
\hline $\begin{array}{c}\text { Cultivar } \\
\text { Odmiana }\end{array}$ & TDF & SDF & IDF & $\begin{array}{c}(1,3)(1,4)-\beta \text {-D-glucans } \\
(1,3)(1,4)-\beta \text {-D-glukany }\end{array}$ & $\begin{array}{c}\text { Protein } \\
\text { Białko }\end{array}$ \\
\hline 'Afrodite' & $19.6^{\mathrm{c}} \pm 0.5$ & $4.4^{\mathrm{c}} \pm 0.3$ & $15.2^{\mathrm{c}} \pm 1.1$ & $3.7^{\mathrm{b}} \pm 0.2$ & $11.6^{\mathrm{b}} \pm 0.3$ \\
'Bordo' & $23.0^{\mathrm{a}} \pm 0.8$ & $5.2^{\mathrm{a}} \pm 0.5$ & $17.8^{\mathrm{ab}} \pm 0.9$ & $4.4^{\mathrm{a}} \pm 0.7$ & $11.8^{\mathrm{ab}} \pm 0.2$ \\
'Henrike' & $21.2^{\mathrm{b}} \pm 1.1$ & $4.5^{\mathrm{c}} \pm 0.2$ & $16.7^{\mathrm{b}} \pm 0.9$ & $3.4^{\mathrm{c}} \pm 0.6$ & $12.0^{\mathrm{a}} \pm 0.2$ \\
'KWS Olof' & $21.7^{\mathrm{b}} \pm 1.1$ & $4.9^{\mathrm{b}} \pm 0.1$ & $16.8^{\mathrm{b}} \pm 0.8$ & $4.1^{\mathrm{a}} \pm 0.3$ & $11.6^{\mathrm{b}} \pm 0.1$ \\
'Tocada' & $24.1^{\mathrm{a}} \pm 1.2$ & $5.3^{\mathrm{a}} \pm 0.4$ & $18.8^{\mathrm{a}} \pm 1.2$ & $4.3^{\mathrm{a}} \pm 0.6$ & $11.9^{\mathrm{ab}} \pm 0.1$ \\
\hline
\end{tabular}

Explanatory notes as in Tab. 1. / Objaśnienia jak pod tab. 1.

Dietary fibre, its fractional composition and in particular the content of $(1,3)(1,4)$ $\beta$-D-glucans are the main distinguishing features of the quality of cereals intended for the production of food with functional features [23, 24, 28]. In the husked barley the content of those components are as follows: TDF $-20 \div 24 \%$ d.m., SDF fraction $-5 \div$ $7 \%$ d.m., IDF $-14 \div 20 \%$ d.m. and the amount of $(1,3)(1,4)-\beta$-D-glucans in the range of $3.7 \div 5.4 \%$ d.m. [26]. In their research study, Cieślik et al [5] reported a relationship between the content of TDF and the content of $(1,3)(1,4)-\beta$-D-glucans both in the cultivar and on the level of nitrogen fertilisation. In the authors' own study that relationship was confirmed too. Also in the authors' own analysis an increase was reported in the content of TDF at $3 \mathrm{~g} \mathrm{~N} /$ pot compared to that at $1 \mathrm{~g} \mathrm{~N} /$ pot as was an increase in the content of SDF and $\beta$-glucans' at 2 and $3 \mathrm{~g} \mathrm{~N} /$ pot compared to that at $1 \mathrm{~g} \mathrm{~N} /$ pot. Moreover, no significant effect of nitrogen fertilisation level on the content of IDF fraction was found (Tab. 3).

The authors' own results are consistent with those presented by Cieślik et al. [5] and Noworolnik et al. $[5,19]$. In all the cultivars examined an increase in the nitrogen dose caused the content of TDF to increase, however there was no interaction between the cultivar and the nitrogen dose in terms of the content of TDF (Fig. 2).

The content of $(1,3)(1,4)-\beta$-D-glucans was $3.4 \div 4.4 \% \mathrm{~d}$.m. and it was similar to the results obtained by Martínez et al. [16] (Tab. 4). Research has shown that both the cultivar and the dose of nitrogen fertilisation affect the content of $(1,3)(1,4)-\beta$-Dglucans. A similar response was observed in the case of spring barley, when the nitrogen fertilisation level was increased; this confirms the results of other studies [5, 19, 28]. There was no interaction between the cultivar and the nitrogen dose as regards the content of glucans (Fig. 3). 


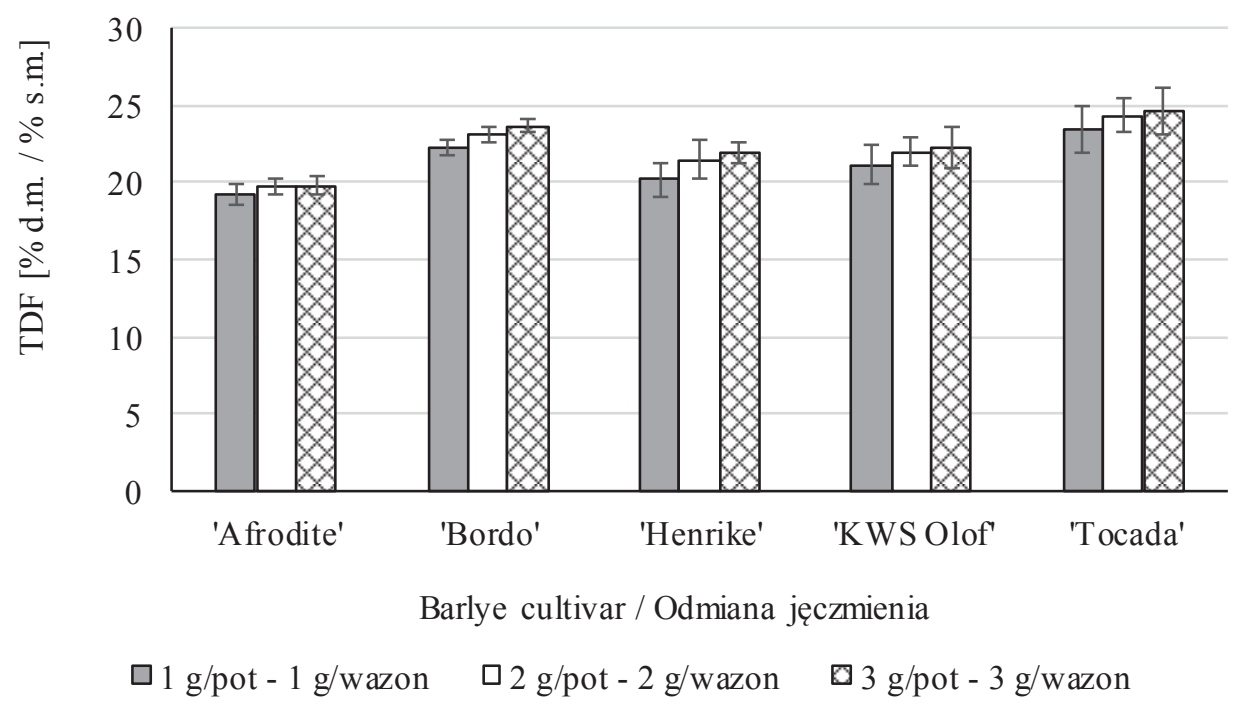

Fig. 2. Effect of barley cultivar and nitrogen dose [g/pot] on content of total dietary fibre (TDF) $[\%$ d.m. $]$

Rys. 2. Wpływ odmiany jęczmienia i dawki azotu [g/wazon] na zawartość błonnika pokarmowego całkowitego (TDF) [\% s.m.]

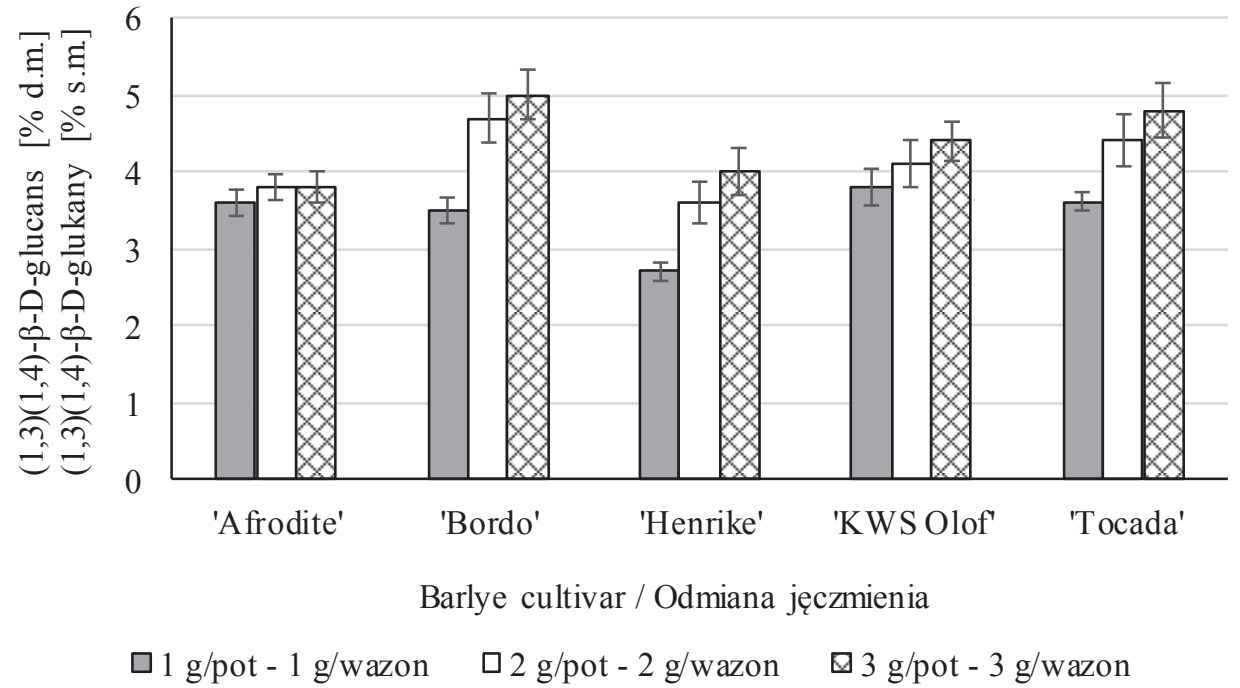

Fig. 3. Effect of barley cultivar and nitrogen dose [g/pot] on content of $(1,3)(1,4)-\beta$-D-glucans [\% d.m.]

Rys. 3. Wpływ odmiany jęczmienia i dawki azotu [g/wazon] na zawartość $(1,3)(1,4)-\beta$-D-glukanów [\% s.m.] 


\section{Conclusions}

1. The research study performed confirmed the significant effect of nitrogen fertilisation level on the grain yield. However, no significant effect of the cultivar was found. Moreover, no interaction between the level of fertilisation and the cultivar was found.

2. The level of nitrogen fertilisation (i.e. the dose of nitrogen fertiliser) had a significant effect on the contents of TDF and $(1,3)(1,4)-\beta$-D-glucans, but no interaction between the level of fertilisation and the cultivar was found. Significantly higher contents of TDF and $(1,3)(1,4)-\beta$-D-glucans were reported in the examined spring barley cultivars at 2 and $3 \mathrm{~g} \mathrm{~N} /$ pot compared to $1 \mathrm{~g} \mathrm{~N} /$ pot.

3. The best varieties for functional food are 'Bordo' and 'Tocada' owing to the highest contents of dietary fibre and $(1,3)(1,4)-\beta$-D-glucans, and a high content of protein.

\section{References}

[1] AACC International: Approved Methods of Analysis. 11 ${ }^{\text {th }}$ ed. American Association of Cereal Chemistry International, St. Paul, Minnesota, USA, 2000.

[2] Ames N., Camille P., Rhymer R.: Issues surrounding health claims for barley. J. Nutr., 2008, 138 (6), 1237S-1243S.

[3] AOAC: Official Methods of Analysis. $20^{\text {th }}$ ed. Association of Official Analytical Chemists International, Rockville, Maryland, USA, 2016.

[4] Brennan C.S.: Dietary fibre, glyceamic response, and diabetes. Mol. Nutr. Food Res., 2005, 49, 560570.

[5] Cieślik E., Pisulewska E., Kidacka A., Witkowicz R.: Ocena wpływu różnych poziomów agrotechniki na zawartość błonnika i beta-glukanów w ziarnie wybranych odmian jęczmienia jarego. Acta Agroph., 2014, 21(1), 17-26.

[6] European Commission: Dietary Fibre. [on line]. Dostęp w Internecie [06.07.2019]: https://ec.europa.eu/jrc/en/health-knowledge-gateway/promotion-prevention/nutrition/fibre

[7] Food and Agriculture Organization of the United Nations: Sesame seed production in 2016. [on line]. United Nations Food and Agriculture Organization Corporate Statistical Database (FAOSTAT). Dostęp w Internecie [26.11.2018]: http://www.fao.org/faostat/en/\#data/QC/visualize

[8] García-Meseguer M.J., Delicado-Soria A., Serrano-Urrea R.: Fiber patterns in young adults living in different environments (USA, Spain, and Tunisia). Anthropometric and Lifestyle Characteristics. Nutrients, 2017, 9(9), \#1030.

[9] Gawęcki J., Roszkowski W.: Rola produktów zbożowych w żywieniu ludzi zdrowych i chorych. W: Produkty zbożowe. Technologia i rola w żywieniu człowieka. Red. J. Gawęcki i W. Obuchowski. Wyd. Uniwersytetu Przyrodniczego w Poznaniu, Poznań 2016.

[10] Institute for Health Metrics and Evaluation (IHME): Global Burden of Disease study 2017. [on line]. Dostęp w Internecie [26.11.2018]: http://ghdx.healthdata.org/gbd-results-tool

[11] James S.L., Muir J.G., Curtis S.L., Gibson P.R.: Dietary fibre: A roughage guide. Int. Med. J., 2003, 33, 291-296.

[12] Kawka A.: Współczesne trendy w produkcji piekarskiej - wykorzystanie owsa i jęczmienia jako zbóż niechlebowych. Żywność. Nauka. Technologia. Jakość, 2010, 3 (70), 25-43. 
[13] Kołodziejczyk P., Michniewicz J.: Ziarno zbóż i produkty zbożowe jako źródła błonnika pokarmowego. Żywność. Nauka. Technologia. Jakość, 2018, 25, 3 (116), 5-22.

[14] Krajewski W.T., Szempliński W., Bielski S.: Plonowanie nagoziarnistych i oplewionych odmian jęczmienia jarego nawożonego azotem. Annales UMCS sec. E Agric., 2013, 68(1), 18-29.

[15] Moreno A., Moreno M.M., Ribas F., Cabello M.J.: Influence of nitrogen fertilizer on grain yield of barley (Hordeum vulgare L.) under irrigated conditions. Span. J. Agric. Res., 2003, 1 (1), 91-100.

[16] Martínez M., Motilva M.J., López de las Hazas M.C., Romero M.P., Vaculova K., Ludwig I.A.: Phytochemical composition and $\beta$-glucan content of barley genotypes from two different geographic origins for human health food production. Food Chem., 2018, 245, 61-70.

[17] Noworolnik K.: Plonowanie i jakość ziarna odmian jęczmienia jarego w zależności od dawki azotu. Fragm. Agron., 2013, 30 (3), 123-131.

[18] Noworolnik K., Leszczyńska D., Dworakowski T.: Wpływ nawożenia azotem na plon ziarna i białka jęczmienia jarego nagoziarnistego i oplewionego. Pam. Puł., 2004, 135, 203-211.

[19] Noworolnik K., Wirkijowska A., Mikos-Szymańska M.: Effect of genotype and nitrogen fertilization on grain yield and quality of spring barley intended for health food use. Bulg. J. Agric. Sci., 2014, 20, 576-580.

[20] Noworolnik K., Wirkijowska A., Rzedzicki Z.: Znaczenie błonnika pokarmowego w diecie oraz jego zawartość w ziarnie jęczmienia jarego w zależności od odmian i gęstości siewu. Fragm. Agron., 2013, 30(3), 132-139.

[21] Pecio A.: Środowiskowe i agrotechniczne uwarunkowania wielkości i jakości plonu ziarna jęczmienia browarnego. Fragm. Agron., 2002, 4(76), 4-112.

[22] Riccioni G., Sblendorio V., Gemello E., Di Bello B., Scotti L., Cusenza S., D’Orazio N.: Dietary fibres and cardiometabolic diseases. Int. J. Mol. Sci., 2012, 13, 1524-1540.

[23] Rzedzicki Z., Sykut E., Wirkijowska A., Nita Z.: Dietary fibre - the most important factor of ford cereals quality. Fragm. Agron., 2008, 1(97), 357-371.

[24] Rzedzicki Z., Wirkijowska A.: Charakterystyka składu chemicznego przetworów jęczmiennych ze szczególnym uwzględnieniem składu frakcyjnego błonnika pokarmowego. Żywność. Nauka. Technologia. Jakość, 2008, 1(56), 52-64.

[25] World Health Orgaznization: Obesity and overweight. [on line]. WHO, 2018. Dostęp w Internecie [6.07.2019]: https://www.who.int/news-room/fact-sheets/detail/obesity-and-overweight

[26] Wirkijowska A., Rzedzicki Z., Sobota A., Sykut-Domańska E., Zarzycki P., Bartoszek K., Kuzawińska E.: Jęczmień w żywieniu człowieka. Pol. J. Agron., 2016, 25, 41-51.

[27] Wyszyński Z., Gozdowski D., Pietkiewicz S., Łoboda T.: Plon ziarna jęczmienia jarego i jego składowe w zależności od rodzaju i dawki nawozów azotowych. Fragm. Agron., 2007, 24(2), 418-426.

[28] Yalçin E., Çelik S., Akar T., Sayim I., Köksel H.: Effects of genotype and environment on betaglucan and dietary fibre contents of hull-less barleys grown in Turkey. Food Chem., 2007, 101, 171176.

\title{
WPLYW NAWOŻENIA AZOTOWEGO NA WARTOŚĆ TECHNOLOGICZNĄ ZIARNA JECZMIENIA JAREGO
}

\author{
Streszczenie
}

Celem pracy było określenie wpływu nawożenia azotowego na zmiany wartości technologicznej pięciu odmian jęczmienia jarego, z przeznaczeniem na cele spożywcze. Doświadczenie wazonowe z jęczmieniem jarym przeprowadzono w hali wegetacyjnej Instytutu Gleboznawstwa i Uprawy Roślin. Odmiany porównywano pod względem wielkości i jakości plonu oraz reakcji na trzy poziomy nawożenia azotem 
$\left(\mathrm{NH}_{4} \mathrm{NO}_{3}\right): 1,2 \mathrm{i} 3 \mathrm{~g}$ N/wazon wegetacyjny. Wykazano istotny wpływ nawożenia azotowego na plon i jakość ziarna badanych odmian jęczmienia. Wraz ze wzrostem wielkości dawki azotu do $3 \mathrm{~g}$ N/wazon istotnie zwiększył się plon ziarna i liczba kłosów z wazonu we wszystkich badanych odmianach jęczmienia jarego, natomiast zmniejszyła się masa 1000 ziaren. Odnotowano istotny wpływ poziomu nawożenia azotem i odmiany jęczmienia na zawartość błonnika całkowitego (TDF) oraz $(1,3)(1,4)-\beta$-D-glukanów, nie stwierdzono natomiast interakcji między poziomem nawożenia a odmianą. Stwierdzono istotnie większą zawartość TDF i $(1,3)(1,4)-\beta$-D-glukanów przy dawce 2 i $3 \mathrm{~g} \mathrm{~N}$ /wazon w porównaniu z $1 \mathrm{~g}$ N/wazon. Wraz ze wzrostem dawki azotu do $3 \mathrm{~g}$ N/wazon stwierdzono istotny wzrost zawartości białka w badanych odmianach jęczmienia. Ze względu na największą zawartość błonnika pokarmowego i $(1,3)(1,4)-\beta$-Dglukanów, jak również dużą zawartość białka zalecane do produkcji żywności mogą być odmiany 'Bordo' i 'Tocada'.

Słowa kluczowe: jęczmień, nawożenie, jakość, błonnik pokarmowy, wazon wegetacyjny 